\title{
INFLUENCE OF ISLAMIC CULTURE ON SPORTS DEVELOPMENT IN NIGERIA (A CASE STUDY OF ADAMAWA STATE)
}

SAMUEL B. C. IHEANACHO, IDRIS ADAMS SABA AND EMMANUEL AKARAH

(Received 9, September 2014; Revision Accepted 11, November 2014)

\begin{abstract}
This study investigated the influence of Islamic Culture on Sport Development in Adamawa State Nigeria. The paper began with a brief synopsis about the position of Muslim's participation in sports visà-vis the outcry of the indigenous inhabitants and their native sport programs. It briefly shed light on the concept of Islamic culture; sport mostly cherished by Islam were outlined while the role of sport in the performance of Islamic religious rights were also highlighted. Efforts were also made by the writers to present the nature, position/state of the Sharia law and its implication on sports participation. The contents of some traditional sports in Adamawa state and the health benefits of engaging in indigenous sports to the children; women, the elderly and the aging persons were discussed. Data revealed that there was great influence of the Islamic culture on sports development on Adamawa State. As a result of the above findings, conclusion were drawn, and so recommendations were made.
\end{abstract}

\section{INTRODUCTION}

The participation in sports programmes be it indigenous or Western has become an important part of this nation's culture as well as other cultures throughout the world. While some cultures strengthens the practice and participation in sporting programs in their communities, others do not, for reasons they consider perfect to their religious inclination. Islam and Christianity as we known, are religions that are alien to Africa and Nigeria in particular. These alien religions have done much to shape certain aspects of African cultures especially the stoppage of the killing of twins in Africa before the coming of Mary Slessor to Nigeria; the introduction of Western Education to Africa and the abolition of slave trade.

As the two religions (Islam and Christianity) were introduced to Africa, Nigeria in particular, each came with the mindset to anchor all their cultural practices on the soil of Africa. Sport wise, Christianity warmly encourages and recognizes the relevance of sport to the well being of their followers as Islam too recognizes the impact of sport on the health of a believer. On Muslims participation in sports, one of the renounced scholar in Islam Sheik Al-Munajjid in (2011), made some statement to the question: "What is the ruling on our body building in Islam?; Are we allowed to put our bodies in structures like the wrestlers so long as we don't show it out and it's to our good"?

This renounced scholar among his responses stated that: "Body building aims to make the body strong and sound, which is an important and desirable goal". He went further to state that; "Islam is concerned with man's wellbeing in both body and soul, and also encourages all kinds of sport that strengthens the body and maintain good health as well as providing relaxation and leisure, such as swimming, shooting, horse riding, sward fighting and wrestling. He also added by quoting from Hadith that, "The strong believer is better and more beloved to Allah than a weak believer".

Samuel B. C. Iheanacho, Department of Human Kinetics and Health Education, University of Calabar, Calabar

Idris Adams Saba, Federal College of Education, Yola, Nigeria.

Emmanuel Akarah, Delta State University, Abraka, Delta State, Nigeria. 
Al-Munajjid stated categorically that in Islam; "If theaim of sport is relaxation and maintaining good health, then sport is permissible but if it involves something Haraam (sinful act), such as missing prayers, uncovering any part of the awrah or mixing with women and so on, then it is haraam (sinful).

In Adamawa state, sport and its programs of activities are an integral aspect of the cultures of the people. They have been practicing their indigenous sports before the advent of Islamic religion that has now absorbed larger number of their people. The role of sports in the cultural setting and practices among these ethnic groups even though organization differs, cannot be overemphasized. Also, the importance attached to sport vary from one community to the other. For instance, while some of the communities use sport as the only means of recreation, others use it for the test of strength and development of physique among youths.

All the twenty one (21) Local Governments Areas in the state, have some indigenous sport that are common to them while others have some that are native to their communities. It is rather very sad today, to hear reactions from various communities of factors inhibiting the growth and development of their indigenous sport in the state. Some of these factors range from the influence of western Education and religion among others.

This paper $\mathrm{x}$-rays the influence of Islamic culture on the development of sport in Adamawa State. It is equally aimed at determining the extent Islamic culture has influenced the youths and adults in sport industry in the state under review.

\section{Islamic Culture Defined}

Islamic culture is a term primarily used in secular academia to describe the cultural practices common to historically Islamic peoples, (Moreh, 1986). As the religion of Islam originated in $7^{\text {th }}$ century in Arabia, the early forms of Muslim culture were predominantly Arab. With the rapid expansion of the Islamic empires, Muslim culture influenced and assimilated much from the Berbers, Indonesian cultures and many other parts of the world.

The outcry of the indigenous inhabitants of the state about the religious factor that inhibit their indigenous sport went to such an extent that they even complained of low turnout of spectators during their cultural sporting festivals. Reports by researchers who conducted studies about the interest of Muslim students in sport participation showed that, there was low level of interest shown by Muslim students in sport especially among women (Carol, 1993); and Adewunmi, 2008). The low interest in sport as observed, by these researchers could be attributed to their adherence to the cultural practices of Islamic doctrines.

It could be inferred from the above therefore that most of the indigenes of this state that have not embraced Islam could have their children in this religion who may not want to get involved in traditional sporting activities or even modernized sports simply because Islam frowns at sport from the point that it could make her followers to miss prayers and other none acceptable ways of life that characterizes sport programs; for instance, mixing of women and men together, hugging between men and women at sport arena, to mention just but a few.

\section{Islamic Sport}

Even though Islam encourage her followers to engage in all kind of sports the following are however sports and plays which Islam Cherishes most especially as contained in Hadith.

- $\quad$ Horse - Ridding.

- $\quad$ Swimming - Learning of the art of swimming.

- $\quad$ Archery - Bows and Arrow Game

- Amusing oneself with the company of one's wife.

There are, however, some sports that are banned in Islam mainly sport that involves killing (i.e. hunting) with restriction on heavy weight boxing according to Islamic Shaira Law.

\section{Sports and Islamic Law}

Even though sport has the above recognized benefits if practiced according to the dictates of Islamic law, the nature of Sharia Law and its implications on human race and sport generally will unveil the much impact and how it checkmates Muslims that go into sports. The nature of Sharia law according to (Adewunmi, 2008); is that 
i) If you steal and the procedures are followed, you lose your hands, as against the law that if you steal, you go to jail;

ii) Women are prevented from sitting together with, men, in buses and public places;

iii) Taking of alcohol or sales of beer and alcohol is forbidden;

iv) Under the Sharia law, it is an offence for male and female to ride in the same bus;

v) It is also an offence for the female folks to take part in politics and sporting activities;

vi) The women are supposed to cover their head always;

vii) They are not supposed to wear short, shirt and trousers in public places and even in school;

viii) It is an offence for males to mingle with females;

ix) The law does not allow the wearing of trousers, which is inevitable in sport participation;

$x$ It does not allow exposing one's body (this is unavoidable in sports);

xi) Women moving, sitting, shaking or embracing men is not allowed. (These happens regularly in sport especially at the point of victory);

xii) Sharia method does not allow women to go out from the children for a long time. They should always be at home with the children. (This is not realistic in sports as sports exposes women to the outside world in which one can spend a greater part of the day outside home).

From the above, it could be observed that the principles of Sharia law runs counter to the general principles and practice that govern sport and so it does not give room for social interaction and healthy development of her followers - the value of sport mostly cherished in Islam. This is so because the law forbids women from exposing their body parts, and does not allow the interaction of male and female which is a natural phenomenon in sports arena. The Female World Cup which recently ended in Germany is a case in point. None of Nigerian female player was of Islamic background. This does not mean that there are no good quality players amongst them but for the restriction in Islamic law they could not.
As observed too from the Islamic law, the female folk are somewhat deprived from participating in sporting activities because there is no sporting venue where one will not see male counterparts, even if the competition is organized for the females alone.

\section{Content of Traditional Sports in Adamawa State}

The following sports form part of the traditional sports of the various ethnic groups in the state. Efforts were made by Bako (1991) and NTI (2000) to outline the sporting activities that are common to majority of the groups as stated:

1) Kokawa - Traditional wrestling (male and female)

2) Farauta - Hunting (male only).

3) Gasankamukifi - Fishing (male and

4) HawanDutse - Rock climbing Mountaineering (male only).

5) Target shooting (native archery) male only especially when shooting at rolled melon fruit from a targeted distance using bows and arrows.

6) Rawa - Dancing (male and female).

7) Jifanmashi - Throwing spears (male only).

8) Tsere - Running (male and female).

9) Sukuwa - Horse riding (male only).

10) Polo - Local hockey (male only).

11) Dambe - Native boxing (male only).

12) Langa - One legged game - and its variations (male and female).

13) Regatta - Sport on water (male and female).

14) Sharo - Flogging game (male only)

15) Dara - Game played on carved wood by two players at a time.

Apart from the above outlined indigenous sport, numerous others not mentioned here exist in pocket of tribes scattered all over the state. The period these sports are competed for are usually when all farm produce or crops have been harvested and men and women retire home to rest until the next farming season.

The reasons for engaging in these traditional sports fundamentally, is for the purpose of relaxation; as a test of strength in individual participants; development of good physique, and above all culture preservation. 
Health Benefits of Engaging in Sports

Sheik-Ali - Munajjd (2011) opined that Islam is desirous of sports due to its health benefits mainly: to maintain good health; helps practice Islam; to engage in Jihad for the sake of Allah and to do the acts of worship which requires physical strength such as Hajj.

If proper attention is paid to participation in all form of sports (traditional or modern), individual and the society according to Dikko (2009), stand to benefit. He categorized them in three groups mainly:

i)

For children and youths:

* Preventing the manifestation of obesity.

* Control the disease risk factors

* Maintaining healthy bones, muscles and joints.

* Controlling body weight.

* Reduction of unhealthy habits like sedentary life style.

ii)

For special issues for women:

* Enhance menstrual cylicity.

* Improved health while pregnant.

* Improvement of foetus.

* Improved health during menopause.

* Improved total body fitness.

iii) For elderly and the aging persons:

* Improved muscles, joints' range of motion (flexibility).
* Prevent/decrease heart related diseases.

* Improvement of life expectancy.

* Decreased muscle waste.

* Improved heart and lung function etc.

* Saba (1992) summarized that:

* the society will be a better place health wise because the health of the society depend on the health of an individual.

* The society will have strong citizens that are capable of facing the challenges of threats in society in terms of war.

* $\quad$ The society will also have strong and healthy women; as a healthy woman is most likely to give birth to strong and healthy child.

To confirm if non participation of indigenous Muslims has any influence on sports development; their choice of job and course of studies for the indigenes in the state; table one and three of this study surveyed the number of Coaches in their state sports council and Physical Education Students of Federal College of Education, Yola where sports is given attention because of a unit for traditional sports in the council and the existence of traditional sports in the learning package (curriculum) in Colleges of Education nationwide.

Table 1: Number of Coaches in Adamawa State Sports Council

\begin{tabular}{|ll|c|c|}
\hline \multicolumn{2}{|c|}{ Items } & Number & Percentage \% \\
\hline 1. & Coaches with Islamic background & 11 & $15.7 \%$ \\
\hline 2. & Coaches without Islamic background & 59 & $84.3 \%$ \\
\hline Total & & $\mathbf{7 0}$ & $\mathbf{1 0 0 \%}$ \\
\hline
\end{tabular}

From the data in table 1 above, it could be concluded that there are fewer coaches with Islamic background with only 11 representing $15.7 \%$ while coaches without Islamic background were 59 representing $84.3 \%$. It could be inferred from this data that, not many Muslims are into this profession in the State.

Table 2: Number of Adamawa State Athletes Camped for the $17^{\text {th }}$ Edition of the National Sport Festival held in Port Harcourt from $27^{\text {th }}$ June $-10^{\text {th }}$ July, 2011

\begin{tabular}{|ll|c|c|}
\hline \multicolumn{2}{|c|}{ Items } & Number & Percentage \% \\
\hline 1. & Athletes with Islamic background & 24 & $11.5 \%$ \\
\hline 2. & Athletes without Islamic background & 184 & $88.3 \%$ \\
\hline Total & & $\mathbf{2 0 8}$ & $\mathbf{1 0 0 \%}$ \\
\hline
\end{tabular}


Table 2 shows that 24 representing $11.5 \%$ of the 208 athletes camped for the purpose of the 2011 National Sport Festival are of Islamic background while 184 representing $88.5 \%$ are without Islamic background. This finding corroborates with the findings of Carol (1993) and Adewunmi (2008) who reported that the negative response or attitude of Muslim boys and girls towards sports in the North especially, is as a result of either actual or perceived restriction placed on them by their culture and ethnicity. Their mode of dressing, Sharia law and beliefs heightens gender differences, with more restricted rules placed upon girls. It was very obvious that religion as well as cultural factors act as powerful forces to restrict their participation rate. This to a great extent hinders sports development in the North (Muslim North). Again a look at the statistic in Table would further show the influence of Islam on sports development.

Table 3: Students enrolment in Physical and Health Education Department (NCE 1 - 3; 2010/2011

\begin{tabular}{|ll|c|c|}
\hline \multicolumn{1}{|c}{$\begin{array}{c}\text { Session) } \\
\text { NCE I }\end{array}$} & Number & Percentage \% \\
\hline 1. & Students with Islamic background. & 3 & $10.34 \%$ \\
\hline 2. & Students without Islamic background. & 26 & $89.66 \%$ \\
\hline Total & $\mathbf{2 9}$ & $\mathbf{1 0 0 \%}$ \\
\hline
\end{tabular}

\begin{tabular}{|ll|c|c|}
\hline & NCE II & NO & $\%$ \\
\hline 1. & Students with Islamic background. & 15 & $22.4 \%$ \\
\hline 2. & Students without Islamic background. & 52 & $77.6 \%$ \\
\hline Total & $\mathbf{6 7}$ & $\mathbf{1 0 0 \%}$ \\
\hline
\end{tabular}

\begin{tabular}{|ll|c|c|}
\hline \multicolumn{2}{|c|}{ NCE III } & No. & \% \\
\hline 1. & Students with Islamic background. & 8 & $25 \%$ \\
\hline 2. & Students with Christian background. & 24 & $75 \%$ \\
\hline Total & & $\mathbf{3 2}$ & $\mathbf{1 0 0 \%}$ \\
\hline
\end{tabular}

Table 3 shows students enrolment in the department of physical and health education of Federal College of Education, Yola for 2010/2011 session. In NCE year one (1) only 3 students representing $10.34 \%$ are with Islamic background while 26 students representing $98.66 \%$ are without Islamic background.

In NCE year two (2) only 15 students representing $22.4 \%$ are Muslims while 52 of them representing $77.6 \%$ are without Islamic background.

The population of NCE year three (3) students in the table (three) shows that there are 32 students. Of this numbers, only 8 students representing $25 \%$ are Muslims while 24 representing $75 \%$ are not.

From the data, the total number of Muslims students in NCE $1-3$ of the college, studying Physical and Health Education stands at 26 as against 102 of the students who are not, for the $2010 / 2011$ session. It goes to explain and to agree with the fewer number recorded in the state camp for the $17^{\text {th }}$ Edition of the National Sport Festival. This is so because the more the population the more the sample even though selection of athletes in the state for the Games was not done on religious basis. Not many Muslims boys and girls do come to enroll in Physical and Health Education course; not to talk of engagement in sport participation as seen in the data in table 3 .

\section{CONCLUSION}

This paper has noted from numerous literatures that Islam recognizes the impact and values inherent in participating in recognized sports. What sound like hatred for sport in Islam is the idea that long period of training in camp during sports interfere with designated time for Islamic prayers and other forms of (Islamic) unacceptable practices, that cannot be avoided in 
sport; such as, men and women mixing together, shaking of hands by opposite sex, hugging especially when victory is recorded and type of wears (outfits) in sports. This influenced sport development generally. Islam however has a very strong belief in cultured preservation like any other religion. As long as this religions keep expanding, less attention will be given to sports by their children, thus sports development would be jeopardized.

\section{RECOMMENDATIONS}

Based on the findings and conclusion drawn, this paper strongly recommend as follows:

1. More number of Muslims (male/female) should be encouraged to take up jobs in the sports council in Adamawa State as coaches, to be able to give attention and encourage young Muslims wishing to go into sport participation.

2. The Muslims that are into sport should be heavily rewarded to attract others into sport participation.

3. There should be early socialization of children with Islamic background in sport because the United Nation's position on sport for all children declared that sport participation is a birth right for all children. So, denying the children and women from sport participation amounts to infringing on their right to the attainment of good health resulting from sport participation.

4. Sport wears should be modernized to cover all the exposed part of the body. Thus attract Muslim women into sport.

5. Students with Islamic background should be encouraged to enroll into the department of physical and health education to acquire the knowledge skills and practice of sports.

6. The Muslim Women Sport Foundation formed in 2001 aimed at increasing the number of Muslim women involved in sports through playing, coaching, refereeing and volunteering should be intensified.

\section{REFERENCES}

Adewunmi, C. M., 2008.Participation of Women in Sports - Sharia Law Implication. Nigeria Journal of Sports Management. Vol.2.

Bako, A., 1991. Langa - Its Rules and Regulations. Allah - Ramma Bookshop Publication. Bichi - Kano.

Carol, B., 1993. "Factors Influencing Ethnic Minority groups Participating in Sports". Physical Education Review Journal, 16(1), $55-66$.

Dikko, M. I., 2009. Physiological Conditioning for Health Promotion. First Edition; Crest Concept Ventures, Zaria.

Moreh, S., 1986."Live Theatre in medieval Islam”, in David Ayalon, Moshe Sharon, Studies of Islamic History and Civilization.Brill Publishers.

National Teacher's Institute Distance Learning System 2000. Course Book on Physical and Health Education, Module 11, Unit 4, Cycle 2.NTI Publications; Kaduna.

Saba, I. A., 1992. Physical Education: A Necessary Education for all. A Seminar Paper Presented at the School of Sciences, Federal College of Education, Yola.

Sheik-Al-Munajjid, M. S., 2011. In Islam Question/Answer (http"//www.islamqa.com/en/ ref/40527. 